УДК [159.955+159.956]

DOI:

Ірина Кишакевич, доктор медичних наук, професор кафедри акушерства і гінекології післядипломної освіти Івано-Франківського національного медичного університету

\title{
ФОРМУВАННЯ ТВОРЧОГО МИСЛЕННЯ ЛІКАРІВ ЗА ДОПОМОГОЮ ПРИЧИННО-НАСЛІДКОВИХ ЗАПИТАНЬ
}

У статті представлено результати активізації мисленнєвих дій лікарів при розв'язуванні ними нестандартних клінічних задач. За результатами аналізу досліджень медичного мислення, констатовано його творчий характер, який проявляється у всіх складових професійної діяльності лікаря: діагностуванні захворювання, лікуванні захворювання, профілактиці захворювання, реабілітаціїхворого та його психологічній підтрими̧і та означено підхід до його вивчення через аналіз мисленнєвих дій при розв'язанні нестандартних клінічних задач.

Констатовано, щуо вивчення творчого мислення лікаря як діяльність, спрямовану на вирішення медичної проблеми, можна проводити виділяючи його когнітивну, операційну та особистісну складові.

Ключові слова: творче медичне мислення; когнітивна; операційна та особистісна складові мислення; причинно-наслідкові запитання; мисленнєвий тренінг.

Табл. 1. Рис. 2. Лім. 11.

Iryna Kyshakevych, Ph.D.(Medicine), Professor of the Obstetrics and Gynecology Postgraduate Education Department Ivano-Frankivsk Medical National University

\section{THE FORMATION OF CREATIVE THINKING OF DOCTORS BY MEANS OF THE CAUSE-AND-EFFECT QUESTIONS}

The article reveals the results of activating the doctors' thinking actions while solving their non-standard clinical problems.

According to the findings based on the analysis of research concerning medical thinking, its creative character, which is manifested in all spheres of the doctor's professional activity, i.e. diagnosing, treating and preventing the disease, rehabilitating the patients and providing them with psychological support, has been proved as well as the approach to its study through the analysis of thinking actions while solving non-standard clinical tasks has been described.

It has been reported that the study of the doctor's creative thinking as an activity aimed at solving a medical problem can be performed by defining its cognitive, operational and personal components.

The article reveals a scientific interest in the problem of activating the creative potential of specialists from various fields, which is carried out by psychologists via the construction of different creativity presuppositions or through external and internal factors. Focusing on algorithmic and heuristic methods that are involved in the search thinking process, and on the dependence of creative thinking efficiency on their combination, the article demonstrates that the ability to combine them will guarantee the effectiveness of finding a solution to creative problems in medicine, where numerous algorithmic techniques of solving medical problems have already been developed.

Having analyzed positive influence of cause-and-effect questions on the process of knowledge acquisition, the author has introduced a training aimed at solving the creative problems with the requirement to answer such questions and to ask them independently in the process of searching the solution by students and doctors.

Enhancing the effect of training based on the doctors' search activities, which is manifested in the effectiveness of search process, less time spent on the achievement of the solution, positive changes in the components of creative medical thinking has been shown. Specifically, thorough examination of problem setting using diverse underlying questions promotes activation of anatomical, pharmaceutical, and histological knowledge, which is a cognitive component of medical thinking. At the same time, increase the level of development of the operating component involves activating basic thinking operations such as analysis, synthesis, comparison, etc. as well as the level of thinking flexibility. Besides, the positive experience of dealing with the complexity of thinking process is gained, which is a sign of positive changes in the personal component.

The author distinguishes three components of creative medical thinking process: the process of understanding, the process of prognosis and the process of approbation; and states that training based on cause-and-effect questions contributes to better quality of all components involved in the search process aimed at solving medical problems.

It has been noted that thinking activity training with the help of the cause-and-effect questions suggested by 


\section{ФОРМУВАННЯ ТВОРЧОГО МИСЛЕННЯЛІКАРІВ ЗАДОПОМОГОЮ ПРИЧИННО-НАСЛІЛКОВИХЗАПИТАНЬ}

the author does not require special preparation and time for its implementation. It can be used by teachers of any discipline during the educational process.

Keywords: the creative medical thinking; the cognitive, operational and personal components of thinking; the cause-and-effect questions; the thinking trends.

П остановка проблеми. Завдання, що постають сьогодні перед спеціалістами, пов’ язані з підвищення ефективності його діяльності, що значною мірою криється урозкритті її творчого потенціалу. Тому, готуючи в стінах вузу майбутнього спеціаліста, слід максимально орієнтувати його на творче ставлення до майбутньої професійної діяльності. Педагогів медичних навчальних закладів в першу чергу повинні цікавити питання, пов'язані 3 формуванням творчого підходу майбутніх лікарів до вирішення фахових завдань. Однак практика показує інше. Поки що в навчальному процес медичних 3ВО все ще переважає тенденція до сліпого нарощування знань та заучування. Тому важливо віднаходити такі методи навчання майбутнього лікаря, який був би підготовлений до вирішення будь-яких, часто несподіваних незнайомих лікарських проблем.

Значна частина дослідників медичної діяльності підкреслює творчий характер професійного мислення лікаря, адже мислення лікаря повинно бути гнучким, здатним до швидкої мобілізації і зміни ходу розмірковувань, коли цього потребують зміни в перебігузахворювання $[1 ; 5 ; 6 ; 8]$.

Такий стан справ робить актуальним дослідження мисленнєвого процесу, спрямованого на вирішення нестандартних, a, отже, творчих завдань у галузі медицини та пошук методів активізації творчого медичного мислення як для самої медицини, так і для психології. При цьому, творче медичне мислення можна означити як специфічну розумову діяльність медичного працівника, що охоплює його знання з медицини, знання про хворого та симптоми його захворювання, особистий досвід медика. Вона проявляється у всіх складових його професійної діяльності: діагностуванні захворювання, лікуванні захворювання, профілактиці захворювання, реабілітації хворого та його психологічній підтримці.

Творче мислення лікаря як діяльність, спрямована на вирішення медичної проблеми, в перше чергу опирається на знання і минулий досвід. В той же час, виникає необхідність виходу за їх межі. Саме тому, із нашої точки зору, актуальним $є$ пошук засобів впливу на формування мисленнєвих дій лікаря взагалі і формування вміння вирішувати нестандартні лікарські проблеми зокрема. Саме творче медичне мислення та методи його активізації в означеному змісті буде в подальшому об 'єктом нашого психологічного аналізу. Дана стаття присвячена аналізу впливу досвіду апробаціiі лікарських проблем спеціальними причиннонаслідковими запитаннями на якість та результативність мислення лікаря при розв'язанні нестандартних ситуативних задач.

Аналіз останніх досліджень і публікацій. Аналіз наукової літератури свідчить, що будь-який мисленнєвий процес - це процес розв'язання задачі (С.Л. Рубінштейн, О.М. Леонтьєв), а процес розв'язання нової задачі для суб'єкта стає творчим (О.М. Матюшкін, К.О. Славська, Л.І. Анциферова О.М. Леонтьев, Я.О. Пономарьов, В.О. Моляко та інші). Кожен творчий мисленнєвий процес поєднує в собі процесуально-динамічний (Л.С. Виготський, С.Л. Рубінштейн, Б.М. Теплов, Г.С. Костюк, П.П. Блонський, В.В. Давидов та інші) та особистісний(С.Л. Рубінштейн, Б.М. Теплов, О.К. Тихомиров, В.О. Моляко та інші) компоненти.

Медичне мислення - це специфіка розумової діяльності лікаря, яка забезпечує ефективне використання даних науки і особистого досвіду стосовно конкретного хворого, конкретного захворювання. Ядром медичного мислення є здатність до розумової побудови синтетичної і динамічної картини хвороби, переходу від сприйняття зовнішніх проявів хвороби до відтворення його внутрішнього перебігу. Саме вміння включати будь-який симптом в логічний ланцюг міркувань є невід'ємною складовою майстерності лікаря [5].

Проблема оптимізації й активізації творчого пошукового процесу може бути розв'язаною при наявності відповідних засобів та прийомів. Про це свідчать наукові результати ряду дослідників, які довели, що спеціальне тренування мислення покращує творчі інтелектуальні здібності. Психологія має у своєму арсеналі багато таких засобів. Деякі з них, як, наприклад, метод дискусій відомі ще 3 часів Платона, другі ("мозковий штурм” А.Ф. Осборна [10], “синектика” У.Д. Гордона [9], “алгоритм розв’ язання винахідницьких задач” Г.С. Альтшуллєра [2], “гірлянди асоціацій” Г.Я. Буша [3], та багато інших) - створені науковцями XX століття. На сьогодні в літературі описано близько трьох десятків таких методик. Всі вони тим чи іншим чином здатні впливати на творчу активність людини, що теоретично обгрунтовано і емпірично перевірено їх розробниками. 


\section{ФОРМУВАННЯ ТВОРЧОГО МИСЛЕННЯЛІКАРІВ ЗА ДОПОМОГОЮ ПРИЧИННО-НАСЛПКОВИХЗАПИТАНЬ}

Різні науковці по-різному підходять до розв'язання проблеми активізації й оптимізації пошукового мисленнєвого процесу. Зазвичай організовується вплив через 1) формування різних передумов творчості; 2) зовнішні фактори; 3) внугрішні фактори.

До передумов творчості прийнято відносити загальний рівень розумового розвитку особистості; рівень знань у тій галузі, в якій здійснюється творчий акт; мотивація; ціль тощо. При цьому, науковцями визнається засаднича роль загального рівня розумового розвитку й рівня знань у тій галузі, в якій здійснюється пошук розв'язку сформованої проблеми. На загал, люди 3 високим показником інтелекту більш здібні до мисленнєвої творчості, але цей взаємозв'язок не $\epsilon$ прямолінійним. Активізувати творчий потенціал енциклопедичними знаннями не вдається. Більш того, людина може бути не дуже освіченою, але мати високий творчий потенціал. Про що свідчить велика кількість раціоналізаторських пропозицій, запропонованих робітниками різних виробництв, які не мали вищої освіти.

До зовнішніх умов, що впливають на творчий процес, слід віднести соціально-психологічний клімат, комфорт умов розумової праці, можливість раціонального вибору інформації. Для того, щоб найкращим чином надихнути людину на творчість, необхідно створити навколо неї обстановку, яка максимально підвищує іiі внутрішню мотивацію до творчості і, що не менш важливо, виключити ті фактори, які їі пригнічують. 3 цього приводу Д. Халперн указує на шість умов, при яких мотивація до творчості спадає: постійне оцінювання; нагляд; винагороди; змагання; обмежений вибір (наприклад, матеріалів); зовнішні фактори, що впливають на вибір роботи [7].

До внутрішніх факторів, що сприяють творчому процесові, належать деякі особистісні якості суб'єкта: лояльність до змін; володіння самомотивацією; не боязнь ризику, невдач, що $є$ невід'ємною частиною пошукової діяльності; терпимість до невизначеності, тощо.

Дослідники творчого мислення вказують, що процес розв'язання творчої задачі визначається продуктивністю функціонування алгоритмічних та евристичних прийомів [4]. При цьому, як відомо, алгоритми - це система операцій, яка забезпечує розв'язання певного, відомого суб'єкту, класу задач. Вона може як сприяти, так і гальмувати пошуковий процес, що спрямований на розв'язання нової задачі. Томузавдання прийомів, що активізують творче мислення, у “знешкодженні” негативного впливу відомих суб' єкту алгоритмічних дій, у перетворенні їх на допоміжні конструкції, що можуть бути використані як у готовому вигляді, так і після певної адаптації. Тобто, будучи чітко регламентованими, алгоритмічні дії не повинні виступати на передній план пошукового процесу, але завжди бути на поготові. Евристичні прийоми містять лише загальні вказівки. Вони лише можуть сприяти пошуку шляхів розв'язання нової проблеми, бути певною мисленнєвою опорою у пошуковому процесі.

Коли мова йде про творчу лікарську діяльність, слід пам'ятати, що в медицині вже існує численна кількість алгоритмічних прийомів вирішення медичних проблем, а результативність пошукових дій значною мірою обумовлена взаємною узгодженістю функціонування алгоритмічних та евристичних прийомів. До завдань тренінгу мисленнєвого процесу належить сприяння поглибленому осмисленню сутності перешкод, складнощів, що характерні для проблемних ситуацій, та з'ясуванню умов і факторів, що допомагають їх обійти. В творчомутренінгу мова йде не стільки про отримання додаткової інформації у цьому напрямі, як про отримання інтелектуально-емоційного досвіду, правильного всебічного оцінювання та подолання нової проблеми. Отже тренінг повинен спрямовуватися не стільки на аналіз абстрактної ситуації, скільки на отримання особистістю власного досвіду подолання проблеми. Інформація про існування перешкод, складнощів повинна стати не привнесеною зовні інструкцієюінформацією, а перетворитися в особистісне надбання, бути перепущеною через суб'єктивний досвід подолання мисленнєвих перешкод. При цьому, оптимізація і активізація пошукового процесу повинна здійснюватися, опираючись на обидва компоненти, через системне залучення суб' єкта в творчу діяльність, що стає можливим при умові спеціальної організації навчання особи певним умінням розв'язання творчих задач.

Саме тому, визначаючи творчий тренінг як один із методів підвищення компетентності людини у сфері творчого мислення, як правило мають на увазі вирішення ряду завдань. По-перше - це сприяння покращанню орієнтації у контексті даного завдання та якісному діагностуванні задачі: віднесення іiї до певної категорії. По-друге - підвищення сприймання контексту нової задачі (виявляти структурні елементи задачі і дані умовою взаємозв'язки між ними в якомога повному об'ємі). По-третє - з'ясування прихованих зв'язків між структурними елементами їх наслідків. По-четверте - 


\section{ФОРМУВАННЯ ТВОРЧОГО МИСЛЕННЯ ЛІКАРІВ ЗА ДОПОМОГОЮ ПРИЧИННО-НАСЛДКОВИХЗАПИТАНЬ}

аналізування i контролювання власних мисленнєвих кроків через детальне обстеження наслідків до яких ці кроки приводять.

Науковцями 3'ясовано, що запитання активізують мисленнєві дії і тих, хто їх задає, і тих, хто на них відповідає. При цьому, вміння ставити причинно-наслідкові запитання $\epsilon$ складним умінням, якого варто навчати учнів, студентів тощо. Зокрема, А. Кінг довела немалу користь упровадження методу взаємних запитань і відповідей при засвоєні знань студентами [11]. Автор розробила серію запитань, які можна задавати, видозмінивши в будь-яких ситуаціях. Дослідниця застосовувала наступні запитальні конструкції: Яким чином можна ... використати для ...?; Що станеться, якщо ...?; Що мається на увазі під ...?; В чому сильні й слабкі сторони ...?; На що схоже ...?; Що ми вже знаємо про ...?; Яким чином ... впливає на ... ?; Яким чином ... пов'язано 3 ...?; Поясніть, чому (як)...?; В чому смисл ...?; Чому важливо ...?; В чому різниця між ... і ... ?; Чим схожі ... і ... ?; Як можна застосувати ... в конкретній задачі?; Який аргумент можна навести проти ... ?; Який ... є кращим і чому?; Якими можуть бути можливі розв'язки задачі?; Порівняйте ... і ... на основі?; Що є причиною ... i чому?; Чи згідні ви з твердженням, що ...?

Серія таких запитань впливає на весь хід пізнання нового матеріалу: актуалізує знання, вміння, навички; активізує мисленнєві операції; підсилює мотиваційний аспект мисленнєвих кроків та інші складники особистісного компонента пошукового процесу.

Bce це породило наш інтерес до з'ясування впливу досвіду ставити і відповідати на подібні запитання на творчий мисленнєвий процес лікаря. Адже, в основі таких запитань лежить глибокий аналіз різнопланової інформації, що може сприяти активізації мисленнєвих кроків і оптимізації пошукових дій при розв'язанні лікарських проблем. Враховуючи, при цьому, що науковці, педагоги вважають процес розв'язання нових задач одним із тих мисленнєвих просторів, де формується творче мислення, ми спробували організовувати активізацію і оптимізацію лікарського мислення через набуття досвіду розв'язування творчих медичних задач в умовах постійної апробації задачі причинно-наслідковими запитаннями. Мета статті - проаналізувати активізуючий вплив досвіду розв'язування творчих лікарських задач в умовах їх постійної апробації причинно-наслідковими запитаннями на творче медичне мислення.

Виклад основного матеріалу. Ми провели тренінгове навчання творчого медичного мислення інтернів та курсантів на базі ІваноФранківського обласного перинатального центру, що $є$ клінічною базою медичного університету. Ми використовували тестові задачі з модуля під назвою "Серцево-легеневої реанімації вагітних".

При складанні програми експерименту, основну увагу було зосереджено на оптимізації суб'єктивних факторів: активізації розумової діяльності особи, формування в неї позитивної мотивації, стійкого інтересу до процесу розв'язання творчих лікарських задач, подолання інертності та стереотипності. Поліпшення об'єктивних факторів (оптимальна форма умови завдання, дозування рівня складності тощо) не входило до мети нашого дослідження.

Учасниками нашого дослідження були студенти-старшокурсники, лікарі-інтерни, лікарі акушери-гінекологи. У експериментальній частині взяли участь 20 осіб: студенти-медики - 5 осіб, студенти-інтерни - 5 осіб; лікарі із стажем до 10 років - 5 осіб; із стажем від 10 років - 5 осіб. Кожен із 20 учасників експерименту розв'язав по десять різних лікарських задач у тренінгових умовах у співпраці з експериментатором і дві (контрольні) задачі після проведення тренінгу. 50 інших учасників дослідження: студенти-медики 10 осіб, студенти-інтерни - 10 осіб; лікарі із стажем до 10 років - 10 осіб; із стажем від 10 до 20 років - 10 осіб; із стажем від 20 років - 10 осіб розв'язували лише дві контрольні задачі. Завданнями клінічних задач було встановити діагноз захворювання та провести віртуальне лікування за вказаним даними анамнезу і результатами діагностики.

Процес розв'язування ситуативних медичних задач у експериментальній групі досліджуваних проходив наступним чином. Після ознайомлення з першою задачею цієї серії, учаснику задавалось кілька запитань, які за змістом були близькі до тих, що описані вище. Ще кілька запитань студент отримував у процесі розв'язування задачі. При цьому експериментатор намагався апробувати як можна більшу частину таких запитань. При розв'язанні наступних задач, до формулювання запитань навколо змісту задачі долучались учасники, а процес розв'язання останніх задач супроводжувався вимогою сформулювати й відповісти на кілька запитань згідно запропонованого взірця.

Умовами виконання студентами контрольної задачі була самостійна пошукова активність на всіх етапах розв'язання, довільний час виконання, припинення роботи за бажанням учасника експерименту. Спостереження за роботою кожного велось індивідуально. 


\section{ФОРМУВАННЯ ТВОРЧОГО МИСЛЕННЯЛІКАРІВ ЗА ДОПОМОГОЮ ПРИЧИННО-НАСЛДКОВИХЗАПИТАНЬ}

По-перше, було з'ясовано, що більшість учасників експерименту звикли самостійно задавати лише прості запитання, які вимагають при відповіді на них поверхневої інформації. Зрідка траплялися запитання-прогнозування: “Що станеться , якщо ... ?”, “Яким чином ... впливає на ...?” тощо. Деякі тексти експериментальних задач взагалі гальмували вербалізацію будь-якого запитання.
Очевидно, що стаж практичної роботи лікаря позитивно впливає на якість пошукової роботи: збільшується кількість правильних розв'язків, зменшується кількість неправильних розв'язків. Однак, такі зміни у пошуковій діяльності лікарів із стажем менші, ніж такі ж зміни у лікарів, які пройшли запропонований нами тренінг. На рис. 2 ми порівнюємо результативність пошукового процесу лікарів із стажем більше десяти років і

Таблиця 1.

Кількісні показники розв'язання контрольних задач учасниками експериментальної та контрольної груп

\begin{tabular}{|c|c|c|c|c|}
\hline \multirow{3}{*}{ Групи } & \multicolumn{4}{|c|}{ Контрольний показник } \\
\hline & \multirow{2}{*}{$\begin{array}{c}\text { Середній час } \\
\text { розв'язання } \\
\text { (у хв.) }\end{array}$} & \multicolumn{3}{|c|}{$\begin{array}{c}\text { Результативність розв’ язання контрольної задачі (у } \\
\text { \%) }\end{array}$} \\
\hline & & розв'язано & $\begin{array}{c}\text { не } \\
\text { розв’язано }\end{array}$ & $\begin{array}{l}\text { неправильно } \\
\text { розв’язано }\end{array}$ \\
\hline експериментальна & 5,7 & 90,0 & 5,0 & 5,0 \\
\hline контрольна & 8,4 & 68,0 & 10,0 & 22,0 \\
\hline
\end{tabular}

По-друге, відбулась зміна результативності пошукового процесу і зменшення затраченого часу на досягнення позитивного результату. Звісно, що отримання чи неотримання розв'язку та час розв'язування задачі $є$ самим загальним критерієм якості пошукового процесу. Проте, Таблиця 1 яскраво ілюструє, що при розв'язанні контрольних задач після тренінгового навчання значно більша частина досліджуваних досягає успіху, при цьому середньостатистичний час, затрачений на розв'язання, суттєво зменшується.

Не менш цікавим $\epsilon$ порівняння результативності пошукового процесу учасників контрольної групи досліджуваних з різним стажем практичної роботи (див рис.1). учасників тренінгового навчання при розв'язанні контрольних задач. Результати порівняння засвідчують, що впроваджена нами програма тренінгового навчання значно активізує пошукові дії, спрямовані на розв'язування лікарської задачі.

Зменшення часу розв'язання контрольних задач експериментальною групою є суттєвою, але не найголовнішою ознакою зміни якості пошукового процесу. Ми виявили зміни у складових компонентах творчого медичного мислення: когнітивного, операційного, особистісно-регулятивного - це, no-mpeme. Зокрема, вплив на когнітивний компонент учасників експерименту проявлявся у актуалізації наявних знань та навичок. Крім того, ретельне

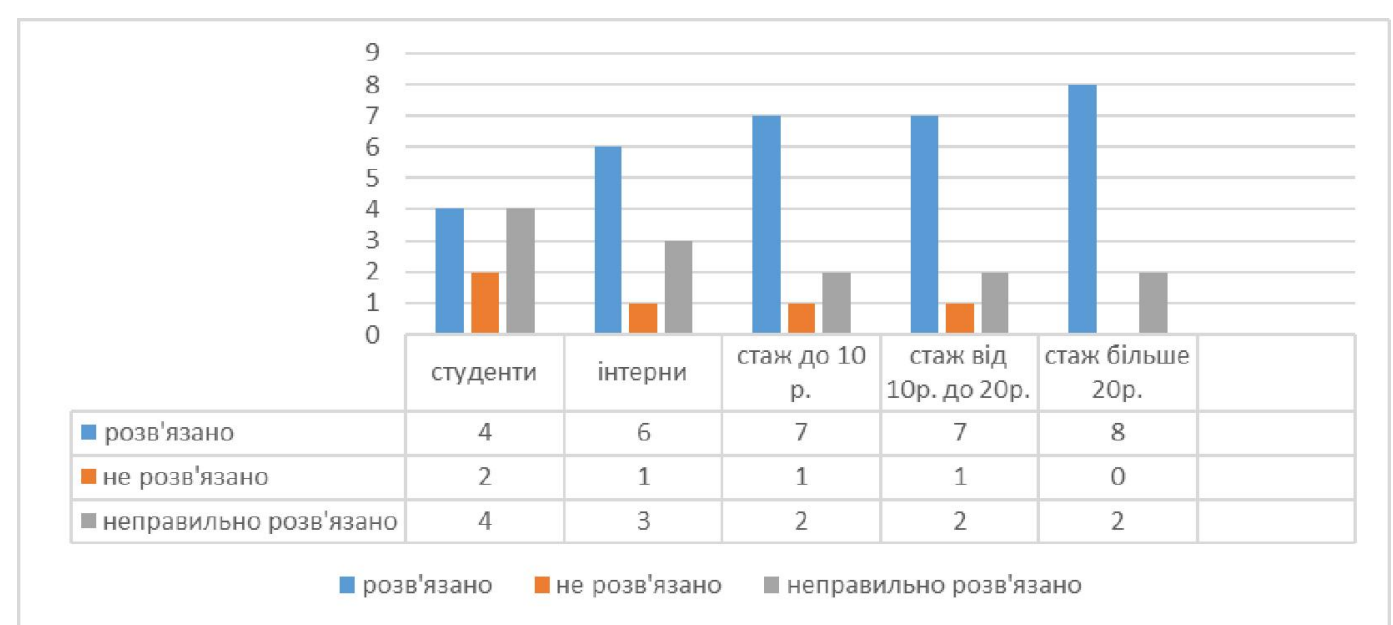

Рис. 1 Кількісні показники розв'язання контрольних задач учасниками контрольної групи $з$ різним стажем практичної роботи 


\section{ФОРМУВАННЯ ТВОРЧОГО МИСЛЕННЯ ЛІКАРІВ ЗА ДОПОМОГОЮ}

ПРИЧИННО-НАСЛДКОВИХЗАПИТАНЬ

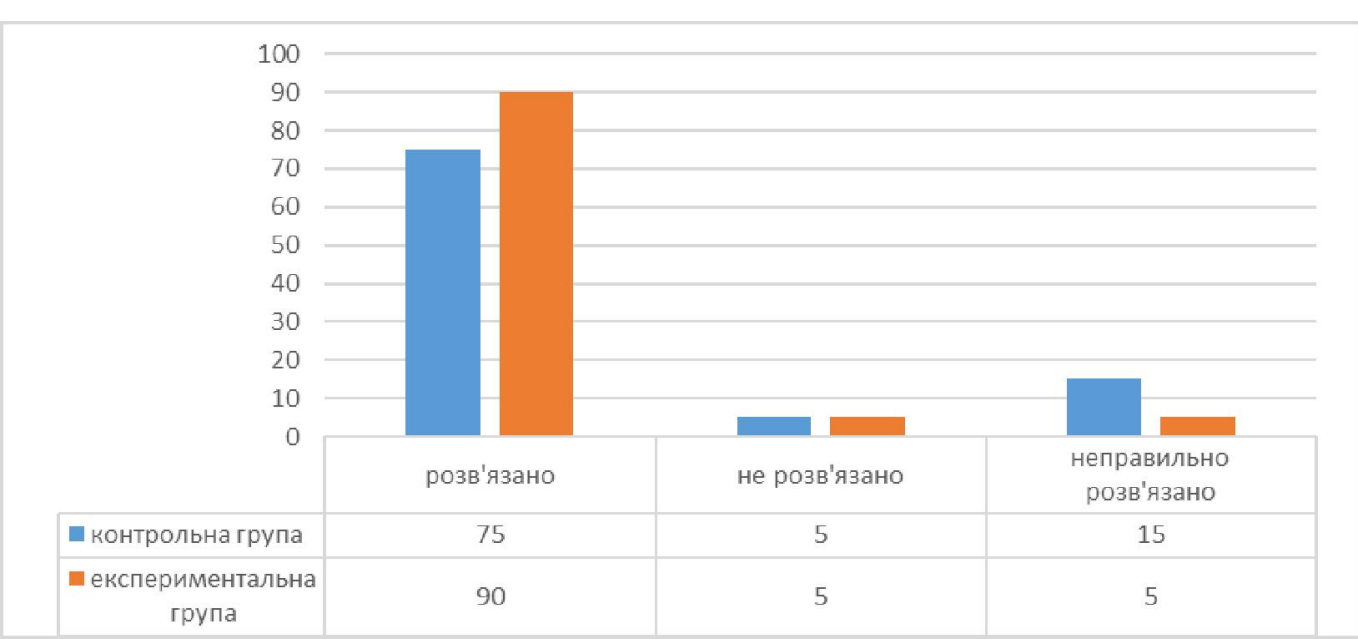

Рис. 2 Кількісні показники розв'язання контрольних задач учасниками контрольної групи із стажем (більше 20 років) практичної роботи та учасників експериментальної групи

обстеження умови задачі глибинними різноплановими запитаннями сприяє активізації анатомічних, фармацевтичних, гістологічних знань, що є компонентами лікарського мислення, оптимізації логічної складової й активізації інтуїтивних знахідок упошуковому мисленнєвому процесі лікаря. Адже ефективність творчого медичного мислення збільшується, коли лікарі вільно оперують всіма цими складовими. Тобто, коли лікар за тією скаргою хворого, яку подано у задачі, вільно прослідковує (навіть передбачає) інші, не описані (і можливо ще не проявлені у хворого) ознаки захворювання; кількісну оцінку (показники лабораторного аналізу, або обстеження спеціальними медичними приладами) переводять у якісну характеристику захворювання, тощо.

Як відомо, процес розв'язання творчих задач розгортається, в першу чергу, як процес їх переформулювання розв'язуючими на “свою” мову з опорою на попередні знання. В ході такого переформулювання, вони отримують нові факти для аналізу, використовують нові поняття i, як результат, активніше висувають гіпотези щодо розв'язання задачі. Застосування запропонованого тренінгу часто спричинювало такі переформулювання під дією вимоги, яка висувається запитанням. Саме це стає причиною нового аналізу умови задачі (аналізом під іншим кутом зору), нового співставлення відомого й невідомого. Під дією таких вимушених переформулювань у процес мислення включаються все нові й нові дані, що веде до глибшого розуміння завдання. Неправильне чи поверхневе розуміння частини умови долається контрумовами, які штучно створюються запитаннями експериментатора, або тими, які складають студенти на його вимогу за відомими шаблонами.

Успішність розв'язання нових лікарських задач, при наявності відповідних базових знань, значною мірою пов'язана 3 умінням оперувати такими знаннями, тобто, 3 операційним компонентом пошукового процесу. Результатом зміни операційного компоненту в першу чергу $є$ якість мисленнєвих операцій, а підвищення рівня розвитку операційного компоненту в результаті тренінгу полягає у активізації основних мисленнєвих операцій: аналіз синтез, порівняння тощо.

Це виражається в більш глибшому аналізі змісту задачі. Можна стверджувати, що після тренінгового навчання студенти глибше вивчають зв'язки між структурними елементами, між структурними елементами та існуючими теоретичними фактами; якісно диференціюють виявлені властивості на загальні й поодинокі. Крім того, виокремленні складові елементи часто розглядають у кількох рівнях: як дрібну окрему структурну одиницю і як складову певного математичного об'єкта.

Очевидно, що більш глибший аналіз структурних складових задачі досягається в тому випадку, коли їх вивчають у найрізноманітніших новоутвореннях, тобто включаючи їх різноманітні взаємозв'язки в якості складових медичних об'єктів. Ми взяли цю характеристику (кількість виявлених взаємозв'язків певних елементів з іншими структурними елементами, що присутні в задачі) за якісну ознаку пошукового процесу лікаря. Було проведено статистичне оцінювання пошукових дій досліджуваних двох груп (20 осіб експериментальної групи та вибірка 


\section{ФОРМУВАННЯ ТВОРЧОГО МИСЛЕННЯЛІКАРІВ ЗА ДОПОМОГОЮ ПРИЧИННО-НАСЛДКОВИХЗАПИТАНЬ}

iз 30 осіб контрольної групи). Оцінювання проводилося за вказаною факторною ознакою і

на основі Q-критерію. Ми отримали $\mathrm{Q}_{\text {експ }}=11$,

при $\mathrm{Q}_{\text {кр. }}=\left\{\begin{array}{c}7, \mathrm{p} \leq 0,05 \\ 9, \mathrm{p} \leq 0,001\end{array}(n-20)\right.$, що свідчить

про суттєву відмінність (із рівнем значущості $\mathrm{p}<0,01)$ пошукового процесу двох вибраних груп за виділеною факторною ознакою.

Детальний аналіз структурних елементів проводиться студентами i за допомогою різнопланового порівняння. Мова йде про якісну зміну процедури порівняння, що мала місце після тренінгового навчання, у процесі розуміння умови задачі; порівняння, спрямованого на відбір необхідних елементів чи теоретичних фактів для реалізації гіпотези розв'язку; порівнянняапробацію отриманого результату з умовою та вимогою задачі.

Слід також підкреслити, що в учасників експериментальної групи при розв'язанні контрольних задач, гнучкість мислення досягає значно вищого рівня. Про це свідчить те, що в учасників експериментальної групи виникає більша кількість варіантів використання властивостей структурних елементів задачі, різноманітність новоутворених комбінацій структурних об'єктів поданих задачею і відомих лікарю теоретичних фактів із значно більшою варіативністю, у порівнянні із учасниками контрольної групи.

Стосовно особистісного компоненту, то варто зазначити, що в учасників тренінгового навчання формується позитивний досвід подолання складнощів у мисленнєвому процесі. Відсутність природної активності компенсується впливом із сторони експериментатора за допомогою описаних вище методів.

По-четверте, тренінгове навчання сприяє більш якісному проходженню складових пошукового процесу, спрямованого на розв'язання лікарських задач: розуміння задачі, формування проекту розв'язку, апробацію мисленнєвих результатів.

Назагал, спостерігалася оптимізація проиесу розуміння у досліджуваних експериментальної групи, яке виражалась у правильному виділенні смислу задачі, у встановленні вірного співвідношення окремих даних задачі між собою, у якісному підборі суб'єктивних еталонів, що необхідні для правильного розуміння задачі. Такі досліджувані на більш високому рівні оперували своїми знаннями, на противагу досліджуваних контрольної групи, які значно частіше демонстрували неефективне, неосмислене використання своїх медичних знань, що приводило до значно більшої кількості помилок.

Формуючи гіпотезу розв'язку, досліджувані експериментальної групи демонстрували більшу варіативність гіпотез, значно глибший зміст цих гіпотез. У процесі пошукової діяльності в так ускладнених умовах вдається значною мірою подолати інертність і стереотипність, бо, вивчаючи умови задач, в багатьох випадках учасники експерименту перестають опиратися на близькі аналоги, в них активізується фантазування, лікарське прогнозування. Тому з'являються більш сміливіші гіпотези, гіпотези, що долучають знання з різних розділів медицини, часто навіть знання з інших галузей науки. Процес формування гіпотези розв'язку стає більш плідним і осмисленим. Якщо мисленнєвий пошук деяких студентів, що при розв'язанні перших задач, які включені у тренінг нагадував броунівський рух, то після тренінгу він перетворюється у цілеспрямоване прогнозування розв'язку. Проміжні результати детальніше обстежуються і тому раціональні мисленнєві знахідки значно рідше відкидаються.

Після впровадження тренінгу активізувалася й оптимізувалася апробація мисленнєвих результатів. Етап перевірки розв'язку стає більш значущим, а необхідність усестороннього апробування знайденого розв'язку стає особистісним надбанням мисленнєвого процесу лікаря. Крім того, на етапі перевірки мисленнєвих результатів учасники експерименту досягають суб'єктивної впевненості у правильності розв'язку. Однак, важливо, щоб така впевненість не наставала передчасно i не набувала викривлення, перетворюючись у самовпевненість, що ми нерідко спостерігали у контрольній групі. На противагу цьому учасники експериментальної групи, виваженіше відносились до результатів своєї мисленнєвої діяльності.

По-n'яте, запропонований нами тренінг 3 використанням причинно-наслідкових запитань не потребує спеціальної підготовки і спеціально виділеного часу для впровадження. Він може бути застосований викладачами будь-якої дисципліни впродовж навчального процесу.

Таким чином, аналіз проведеного дослідження дає право стверджувати, що використаний у нашому дослідженні тренінг із впровадженням причинно-наслідкових запитань сприяє оптимізації творчого медичного мислення і веде до позитивних змін всіх його базових компонентів: когнітивну, операційну та особистісну; оптимізує 
всі його складові: розуміння задачі, формування проекту розв'язку, апробацію мисленнєвих результатів.

Перспективою подальших досліджень даної проблеми є вивчення впливу тренінгу із впровадженням причинно-наслідкових запитань на функціонування мисленнєвих стратегій лікаря.

\section{ЛІТЕРАТУРА}

1. Абаев Ю. К. Логика врачебного мышления / Ю.К. Абаєв // Мед. новости. - 2007. - №5. - С. 16-22.

2. АльтшуллерГ.С. Теория решения изобретательских задач. - М.: Моск. рабочий, 1979. - 174 с.

3. Буш Г.Я. Основы эвристики для изобретателей. - Рига: Знание, 1977. - 95с.

4. Моляко В.А. Психология конструкторской деятельности [Текст] / Моляко В.А.- М.: Машиностроение, 1983. - 136 с., с. 18.

5. Наумов Л. Б. Легко ли стать врачом / Л.Б. Наумов. - Ташкент: Медицина, 1983. - 464 с.

6. Попов Н. В. Философия и методология научного медицинского познания / Н. В. Попов. К., 1998. - 172 c.

7. Халперн Д. Психология критического мышления[Текст] / Халперн Д. - СанктПетербург, 2000. - 503 с.

8. Чазов Е. И. Опыт философско-методологического анализа врачебной диагностики / Е. И. Чазов, Г. И. Царегородцев, Е. А. Кротков // Вопр. философии. - 1986. - № 9. - С. 65-85.

9. Gordon W. Metaphor and invention // The creativity Questions. Durham, NC: Duke University Press. - 1976.

10. Osborn A.F. Applied imagination. Principles and procedures of creative problem solving. - New York: Scribner's. - 1963.

11. King A. Inquiring minds really do want to know: using questioning to teach critical thinking. / Psychologists teach critical thinking [Special issue]. // Teaching of Psychology. - 1995. - P. 13-17.

\section{REFERENCES}

1. Abaev, Yu. K. (2007). Logika vrachebnogo myshleniya [Logic of medical thinking]. Med. novosti. No.5, pp. 16-22.[in Russian].

2. Altshuller, G. S. (1979). Teoriya resheniya izobretatelskikh zadach [The theory of Inventive Problem Solving]. Moscov: Mosk. rabochiy, 174 p.[in Russian].

3. Bush, G. Ya. (1977). Osnovy evristiki dlya izobretateley [The basics of heuristics for inventors]. Riga: Znanie, 95p. [in Russian].

4. Molyako, V.A. (1983). Psikhologiya konstruktorskoy deyatelnosti [Psychology of design activities]. Moscov: Mashinostroenie, 136 p.,p. 18. [in Russian].

5. Naumov, L. B. (1983). Legko li stat vrachom [Is it easy to become a doctor]. Tashkent: Meditsina, 464 p. [in Russian].

6. Popov, N. V. (1998). Filosofiya i metodologiya nauchnogo meditsinskogo poznaniya [Philosophy and methodology of scientific medical knowledge] Kyiv, 172 p. [in Russian].

7. Khalpern, D. (2000). Psikhologiya kriticheskogo myshleniya [Psychology of critical thinking]. SanktPeterburg, 503 p. [in Russian].

8. Chazov, Ye. I., Tsaregorodtsev, G. I. \& Krotkov, Ye. A. (1986). Opyt filosofsko-metodologicheskogo analiza vrachebnoy diagnostiki [The experience of philosophical and methodological analysis of medical diagnostics]. Vopr. filosofii. No.9, pp. 6585. [in Russian].

9.Gordon, W. (1976). Metaphor and invention. The creativity Questions. Durham, NC: Duke University Press. [in English].

10. Osborn, A.F. (1963). Applied imagination. Principles and procedures of creative problem solving. New York: Scribner's. [in English].

11. King, A. (1995). Inquiring minds really do want to know: using questioning to teach critical thinking. Psychologists teach critical thinking [Special issue]. Teaching of Psychology. P. 13-17. [in English].

\section{Стаття надійшла до редакції 10.04.2018}

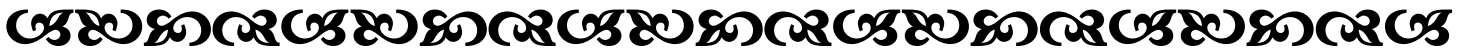
досягти".

"Ж⿱㇒㠯 розум людини може осягнути $і$ в що він може повірити, те він здатний Наполеон Хілл америқанський письменник, журналіст і психолог

“Молода людина повинна шуқати ту єдину ісқру індивідуальності, яқа відрізняє ї̈ від іншихлюдей, і розпалювати ї̈ всіма силами... Не давайте ісқрі згаснути". 